Современное состояние гуманитарных и социально-экономических наук: сборник научных трудов по материалам Международной научно-практической конференции 31 января 2019 г.: в 3-х ч. Ч. ІІ / Под общ. ред. Е.П. Ткачевой.

Белгород : ООО Агентство перспективных научных исследований, 2019.

\title{
И.Э. ГУКОВСКИЙ: БОЛЬШЕВИК, КАПИТАЛИСТ, СОВЕТСКИЙ НАРКОМ, ИЗГОЙ
}

Ольшевский В.Г. канд. экон. наук, доцент, профессор, Почётный доктор Российской академии естествознания, Беларусь, г. Минск

В статье впервые в исторической и социально-экономической литературе обозначены контуры комплексного исследования деятельности одного из малоизвестных российских революционеров, наркома финансов РСФСР И.Э. Гуковского, большевика, ставшего капиталистом, а затем одиозной фигурой «ленинской гвардии». Проведённый анализ позволяет сделать вывод о необходимости существенного уточнения истории первых лет советской власти, а также психологического портрета В.И. Ленина.

Ключевые слова: Наркомфин РСФСР; В.Р. Менжинский; А.И. Бриллиантов; И.Э. Гуковский; В.И. Ленин; финансовая, нефтяная, внешнеэкономическая политика.

Казалось бы, имя Исидора Эммануиловича Гуковского известно интересующимся историей первых лет советской власти и экономической политикой того периода. Он вскользь упоминался во многих статьях и книгах. Тем не менее даже хорошо ориентирующиеся в «кремлёвских» архивах историки вынуждены были относить его к числу тех советских руководителей, данные о которых «не являются исчерпывающими, а иногда, к сожалению, и вовсе недостаточны» [14, с. 46]. Но очевидно, что недостаток данных не может быть достаточным основанием для того, чтобы в книге о первых советских наркомах, изданной уже в период приобщения к исторической правде, упомянуть его лишь походя, одной строкой. Здесь есть отдельный очерк о выдвиженце В.И. Ленина И.И. Скворцове-Степанове, считающем себя «плохим практиком финансового дела» [35, с. 198], не принявшем пост, но всегда называемом первым наркомфином. Есть и эпическое повествование о В.Р. Менжинском, назначенном декретом СНК 30 октября 1917 г. временным заместителем наркома, который, по свидетельству его подчинённых, занимался преимущественно борьбой с саботажем банковских служащих и вообще не вникал в собственно финансовую работу. Декретом СНК от 20 января 1918 г., 
сформировавшим коллегию НКФ, он был официально назначен наркомом. Однако это произошло на следующий день после того, как по соглашению ЦК РСДРП(б) и ПЛСР наркомом финансов без портфеля был назначен председатель финансового отдела ВЦИК левый эсер А.И. Бриллиантов [35, с. 448]. Энциклопедический словарь братьев Гранат «Деятели СССР и революционного движения России» назвал его вторым после СкворцоваСтепанова наркомом финансов в период с 19 января (1 февраля) по 18 марта 1918 г. А Менжинский в списке наркомов здесь вообще отсутствует [10, с. 827]. В исторической и справочной литературе отрицается выполнение Бриллиантовым функций наркомфина [см., напр.: 15, с. 52; 25]. Однако хорошо знающий НКФ изнутри помощник наркома Д.П. Боголепов в опубликованной в 1925 г. статье подтверждал, что Бриллиантов в течение некоторого времени руководил наркоматом [1, с. 171]. Хотя этот факт ещё не стал общепризнанным, можно считать установленным, что третьим наркомом финансов Советской России, хотя и «без портфеля», был малоизвестный левый эсер с трагической судьбой [см.: 31].

Ленин, выполнив одно из условий коалиционного соглашения с ПЛСР, не собирался надолго допускать даже символическое участие своих временных партнёров и одновременно политических соперников в решении финансовых вопросов. Это было частью интриги и по «сотрудничеству» с временными попутчиками, и по управлению Совнаркомом, в частности реализацией решения вождя о перемещении Менжинского из НКФ и его замены Гуковским [см.: 30, с. 30-31]. Ещё 7 января 1918 г. ставший «финансистом» бывший выпускник юридического факультета Петербургского университета был введён в подотдел борьбы с преступлениями по должности банковских чиновников ВЧК. А 9 марта, накануне переезда правительства в Москву, решением ЦК партии он был включён в состав Петроградского «Боевого правительственного центра», утверждён членом Президиума Петросовета, членом коллегии Наркомюста, в котором он возглавил уголовный сектор; ему было поручено также руководство совместно с М.С. Урицким Петроградской ЧК. В тот же 
день, 9 марта, после определённой психологической подготовки демонстративного противопоставления его Лениным Бриллиантову, бывший в 1917 г. до октябрьского переворота казначеем Петроградского комитета (ЦК) большевиков Гуковский был назначен заместителем наркома. Только после ухода левых эсеров из правительства в знак протеста против Брестского мира и отъезда Бриллиантова не в новую столицу, а в делегировавшую его в Учредительное собрание Уфу Гуковский официально стал наркомом финансов.

Приведённые факты остались за пределами внимания авторов упомянутой выше книги о первых советских наркомах, в которой Гуковский «присутствует» лишь в высказывании: «Менжинский по решению ЦК партии был оставлен в Петрограде. Руководство Наркомфином было возложено на его заместителя Гуковского» [35, с. 331].

Внешне это выглядело чрезвычайно странным. Большевистский партийный стаж Гуковского исчислялся с 1898 г. «Архивариус революции» Н.Н. Суханов называл его одним из «старых большевистских “генералов”» [41, c. 20]. Будучи назначенным на столь значимый пост по личной инициативе Ленина, он активно участвовал в дискуссиях по вопросам экономических преобразований и, в отличие от своих предшественников, - первым руководителем ведомства, который со знанием дела занялся собственно финансовой работой. Отношение к Гуковскому советской, а затем и постсоветской истории Отечества было «неровным» и менялось весьма симптоматично. В 1-м издании Большой Советской Энциклопедии в 1930 г. он был охарактеризован как «политический деятель, коммунист» [2, стлб. 783 784]. Во 2-м и 3-м изданиях БСЭ (с 1949 по 1978 гг.) статьи о Гуковском отсутствуют. В опубликованной в 1977 г. энциклопедии «Великая Октябрьская социалистическая революция» он также не упоминался. Более того, и в менее торжественно-монументальной, изданной к тому же юбилею научной работе, он вообще не значился в числе первых советских наркомов финансов [6, с. 16]. Правда, в 1983 г. в Советском энциклопедическом словаре он был представлен весьма достойно: «Советский государственный, партийный деятель. Член 
КПСС с 1898. Участник Революции 1905-07, Февральской и Октябрьской 1917... В 1918 зам. наркома, нарком финансов» [37, с. 349]. Но в 3-м, дополненном, издании энциклопедии «Великая Октябрьская социалистическая революция» 1987 г. информация о казначее большевиков также отсутствует. Об этом, как его называли, заслуженном большевике и наркоме в советское время не было опубликовано ни одной статьи.

Обозначенные зигзаги и изъяны советской исторической памяти отчасти объяснялись спецификой соотношения знания и власти. Историкам, имевшим доступ к спрятанной в спецхранах литературе российского зарубежья, были известны изданные в начале 1930-х годов публикации высокопоставленных невозвращенцев [20; 40], в которых скомпрометировавший себя полпред и торгпред РСФСР в Эстонии Гуковский характеризовался как коррупционер, взяточник, пьяница, расхититель социалистической собственности, аморальный перерожденец, олицетворяющий пороки кланового большевизма. Особенно жёстко критиковал Гуковского прибывший в Ревель в июле 1920 г. ему на смену в должности представителя НКВТ бывший заместитель наркома этого ведомства Г.А. Соломон (Исецкий). В опубликованных в 1930 г. в Париже воспоминаниях «Среди красных вождей. Лично пережитое и виденное на советской службе» он привёл множество фактов заключения Гуковским ущербных, юридически не обеспечивающих интересы государства договоров о поставках закупленных в различных странах товаров, завышения цен на них при снижении требований к их качеству, вопиющих финансовых нарушений, позволяющих государственному закупщику в лице Гуковского и его сотрудников получать в виде взяток от 10 до $40 \%$ общей суммы сделок. Часто приезжавший в Ревель бывший финансовый советник уполномоченного СНК по закупке паровозов в Европе Ю.В. Ломоносова, впоследствии заместитель начальника валютного управления наркомата финансов М.Я. Ларсонс также подтверждал активно обсуждаемое в прессе многих европейских стран «невероятное взяточничество среди личного состава представительства»во времена Гуковского [20, с. 47]. 
К удивлению Соломона его требования о проведении тщательной ревизии торгово-хозяйственной деятельности представительства Рабочекрестьянской инспекцией и наказании виновных натолкнулись на сопротивление многих московских руководителей, фактически взявших Гуковского, бывшего незадолго до этого членом коллегии РКИ, под свою защиту. По его оценкам, совпадающим с мнением Л.Б. Красина, Гуковским в течение деятельности в Эстонии «было дадено» в виде различных, в том числе продовольственных, подарков практически всем высшим руководителям наркоматов и ЦК партии за исключением неподкупных В.И. Ленина и А.И. Рыкова. Наиболее активных и настойчивых ходатаев за Гуковского Соломон называл «уголовной компанией», «уголовными преступниками», «уголовными друзьями» своего подзащитного. В их числе он выделял в первую очередь курирующих деятельность представительства члена коллегий наркомата госконтроля и ВЧК В.А. Аванесова, секретаря ЦК РКП(б) Н.Н. Крестинского, наркома по иностранным делам Г.В. Чичерина, ставшего заместителем наркома внешней торговли, называемого Л.Б. Красиным «без пяти минут государственным человеком» А.М. Лежаву [см.: 40, с. 341-342, 344, 355, 356, 394 и др.]. Проявляемая ими «большевистская солидарность» и круговая порука усугублялась основными чертами характера Гуковского, каковыми, по определению Соломона, были «ничем не сдерживаемый, грубый, чисто животный эгоизм, половая распущенность, отсутствие чувства элементарной стыдливости, выражавшейся в его моральной оголённости, алкоголизм, хитрость, жестокость, лживость, предательство, т. е. в конечном счёте полный дефект морали» [40, с. 499-500]. Совокупность всех или большинства этих черт, проявляющихся как «великая мерзость человеческая, великая человеческая пошлость», «всё нечистое, всё блудливое, всё ворующее и пожирающее народные средства», Соломон обозначил термином «гуковщина» [40, с. 388, 422, 496], нередко отождествляя её со всеми, направленными против него действиями. Но сам он по своему происхождению, воспитанию, чертам характера не мог не вызывать раздражения со стороны 
многих своих партнёров. Будучи выходцем из потомственной дворянской семьи, обладая блестящим умом, широкой образованностью, врождённым чувством справедливости он в молодые годы пользовался большим авторитетом среди революционеров. Ещё в юности стал близким другом Л.Б. Красина. Активно участвуя в деятельности «Союза борьбы за освобождение рабочего класса» он общался с А.И. Ульяновой и её мужем М.Т. Елизаровым, М.И. Ульяновой. Уже после раскола партии, несмотря на свой менышевизм, будучи в эмиграции в Бельгии, как избранный секретарь Брюссельской группы РСДРП несколько раз принимал у себя Ленина. В эмиграции также приятельствовал с В.Р. Менжинским. После захвата большевиками власти Соломон по протекции Красина стал первым секретарём полпредства РСФСР в Германии, а затем руководителем консульства в Гамбурге. После высылки в ноябре 1918 г. советского представительства из Берлина Соломон по болезни не смог уехать из Германии, вместе с женой был арестован, около двух месяцев провёл в тюрьме и по настоянию врача был переведён для продолжения лечения в санаторий. Только 6 июля 1919 г. он, оставив жену за границей, вернулся в Москву и вскоре по требованию уже ставшего руководителем сразу двух наркоматов Красина был назначен его заместителем по комиссариату торговли и промышленности. Ленин не возражал, но потребовал немедленно оформить членство Соломона в большевистской партии, что и было сделано. Однако официально он не был утверждён в новой должности ни ЦК, ни Совнаркомом. Красину пришлось ограничиться изданием соответствующего приказа по ведомству. Большевистские функционеры не доверяли «перекрасившемуся» идеалистуменьшевику, интриги против Соломона постоянно сопровождали его и в Германии, и в Москве, и в Ревеле, и в Лондоне, где он, опять-таки по протекции своего всесильного друга, стал директором созданной советским правительством торгово-закупочной фирмы «Arcos Ltd». Это и сделало его, в конечном счёте, невозвращенцем. Соломон был абсолютно честным, порядочным человеком, он отдавал всего себя работе, служению стране и 
требовал того же от своих подчинённых. Однако он, как следует из его изложения, скорее всего не знал об особых отношениях в партии, обусловленных финансированием революционной деятельности до захвата власти, участием в нём В.И. Ленина, И.В. Сталина, А.М. Горького, М.Ф. Андреевой, Л.Б. Красина и, наконец, самого Гуковского. А это изменило бы его восприятие названных и других партийцев. Он также не понимал глубинной, безнравственной сути революционного большевизма, критикуя его частные проявления в деятельности действительно безнравственных с точки зрения обычных представлений конкретных его представителей. Нельзя забывать, что никто иной как Ленин, фактически цитируя известного революционной непорядочностью С.Г. Нечаева, говорил 2 октября 1920 г. на III съезде комсомола: «Для нас нравственность подчинена интересам классовой борьбы пролетариата» [21, т. 41, с. 310], в реальной жизни она была подчинена интересам большевиков и их лидера [см.: 28].

Самым главным в контексте темы статьи следствием разоблачений Соломона стало то, что, пригвоздив Гуковского (при широком подходе гуковщину) к позорному столбу, он надолго вывел его фигуру за пределы всестороннего, исторического анализа. Воспоминания Соломона ещё при жизни автора были переведены на французский, немецкий, английский, шведский и голландский языки, так что и зарубежные историки им абсолютно не интересовались.

Исследования, проведённые автором в 1990-х гг., выявили скрытую от поверхностного наблюдения причину явно недостаточного внимания советской истории к Гуковскому. Дело в том, что в 1918 г. он был единственным реалистом в советском правительстве (по некоторым вопросам с ним был солидарен лишь Г.Я. Сокольников), противодействующим осуществляемому получившими власть большевиками курсу на ликвидацию товарного производства, рынка, денег и других, как тогда считали, «остатков капитализма». В течение определённого времени он активно сопротивлялся реализации утопичных теоретических построений В.И. Ленина, Н.В. Бухарина, 
Ю.М. Ларина и других теоретически марксистски мыслящих большевиков [см.: 21 , т. 33 , с. 101,116 ; т. 34 , с. 224 ; т. 35 , с. $174-175,199,250$; т. 36 , с. $74-75 ; 3$; ; $17 ; 19 ; 32]$.

В представленной Гуковским в докладе ВЦИКу 15 апреля 1918 г. программе экономической стабилизации содержалась система мер не только финансового, но и общехозяйственного, даже идеологического свойства. В числе его предложений были: радикальное сокращение расходов, в том числе за счёт введения бесплатности общественной деятельности; упорядочение налогообложения, увеличение существующих и введение новых прямых и косвенных налогов, отмена всякого рода контрибуций; признание сосуществования частного производства и торговли и национализированных предприятий; восстановление кредита, оздоровление и укрепление денежного обращения; привлечение к производительной деятельности всех работников, живущих в пределах Советской республики, использование всех материальных и моральных сил страны [1, с. 173-174; 30, с. 37-38]. Фактически Гуковский предложил то, что впоследствии получило название «новой экономической политики», провозглашённой под угрозой крушения советской власти признавшим свои ошибки Лениным [см.: 21, т. 44, с. 156, 157, 159]. Предпринятая в 1918-1921 гг. попытка построения «безденежного коммунизма», впоследствии преобразованного в безрыночное «социалистическое общество», в сочетании с подчинением нравственности «интересам классовой борьбы пролетариата» дорого обошлась народам не только Советской России, но и СССР [см.: 8, с. 117-147; 27].

Противодействие Гуковского бесшабашной национализации и политике «унижения рубля» привели к его отставке 16 августа 1918 г. с поста наркома. В советской историографии и некоторых источниках современных авторов утверждалось, что она была вызвана его болезнью [см., напр.: 5, с. 73; 6, с. 233; 38 , с. $139 ; 39$, с. 244]. На самом деле её непосредственной причиной было сопротивление Гуковского задуманной и маниакально подталкиваемой Лениным денежной реформе. О фактических обстоятельствах по существу 
скандальной отставки наркома свидетельствует опубликованная в XXI Ленинском сборнике переписка вождя с Гуковским и Лариным на заседании СНК 16 августа [22, с. 179-181]. Поразительно то, что и в наши дни некоторые потомственные доктора исторических наук по-прежнему утверждают, что усиленно проталкиваемая Лениным денежная реформа была направлена на «подрыв финансовой мощи буржуазии». Ленин неоднократно подчёркивал, что не только буржуазия, но и все граждане страны должны стать служащими и рабочими, работающими по найму у государства «диктатуры пролетариата». По Ленину, социализм - это, прежде всего, учёт и контроль. Но только при отсутствии у людей неконтролируемых государством денег «этот контроль станет действительно универсальным, всеобщим, всенародным, тогда от него нельзя будет никак уклониться, “некуда будет деться"» [21, т. 33, с. 101]. Подобные проекты вызывали сомнения в их осуществимости, неприятие и противодействие даже у сохраняющих здравомыслие большевиков.

Гуковский был более чем благоразумным человеком, но и его благоразумие не было беспредельным. После отставки он потерял предоставленную ему по распоряжению Ленина в мае квартиру в Кремле, утратил некоторые другие преимущества высокого положения и близости к вождю. Некоторое время он продолжал работать в коллегии НКФ и нефтяном комитете, был введён в коллегию Наркомата госконтроля, в декабре стал его представителем в Малом СНК. Но при этом пришлось не только «поступиться принципами», но и стать беспринципным. Если раньше он был решительным противником уничтожения денег, превращения банковской системы в центральную общественную бухгалтерию, «в единый аппарат счетоводства и регулирования социалистически организованной хозяйственной жизни всей страны в целом» (Ленин), т.е. нормальным реалистически мыслящим экономистом [см.: 30, с. 34-37], то уже через три месяца, к II Всероссийскому съезду совнархозов, он присоединился к радикальному, экономически и психологически малограмотному, большевистскому мэйнстриму. Перерождение проявилось не только в этом. В целом, именно после 
применения к нему ленинского «силового воздействия» и «духовной ломки» Гуковский претерпел весьма печальную эволюцию, деградацию личности, проявившуюся в угодничестве и низкопоклонстве по отношению к влиятельным людям, злоупотреблении алкоголем, безнравственности, неразборчивых связях и т.д. и т.П. Но это отнюдь не означает, что он стал совершенно недееспособным работником. Названные грехи были совсем не редкими среди большевистских руководителей. В случае с Гуковским они усугубились и стали острой личной и государственной проблемой только после его назначения полпредом и торгпредом РСФСР в Эстонии, когда ему по решению ЦК партии были предоставлены в бесконтрольное распоряжение огромные средства в валюте, золоте и ювелирных изделиях, предназначенных для продажи в Европе [29].

Суть и глубину психологической драмы и трагедии Гуковского позволяют в какой-то мере прояснить частично опубликованные результаты исследований уже ушедшего из жизни А.В. Островского. По его сведениям [33, c. 618-619], Гуковский в 1904 г. после истечения пятилетнего срока ссылки в Енисейской губернии поселился в Баку, где работал бухгалтером, а затем главным бухгалтером в городской управе, вошёл в состав ревизионной комиссии нефтепромышленной фирмы «А.С. Меликов и ${ }^{\circ}{ }^{»}$. При этом он участвовал в деятельности социал-демократической организации под именем Фёдора Измайловича. В том же 1904 г. стал представителем ЦК в Баку. Здесь познакомился с И.В. Сталиным. По некоторым данным, впоследствии, находясь в тюрьме, руководил расследованием дела о нарушении им партийной дисциплины. По свидетельству Г.А. Соломона, после революции пользовался его поддержкой: Сталин «был за него горой». В октябре 1905 г. стал одним из спонсоров и организаторов газеты «Новая жизнь» в Петербурге и секретарём её редакции. После её закрытия привлекался к дознанию, арестовывался. В 1907 г. купил участок нефтеносной земли, вскоре вернулся в Баку. Отошёл от революционной деятельности, но продолжал участвовать в систематическом финансировании фонда помощи арестованным и ссыльным. С 1912 г. жил в 
северной столице, где возглавлял контору Петербургского нефтепромышленного общества, председателем правления которого был А.И. Путилов. В 1914 г. основал фирму «И.Э. Гуковский» с уставным капиталом в 300 тыс. руб., впоследствии увеличившимся до полумиллиона. В адресной книге «Весь Петроград» на 1916 г. почётный гражданин И.Э. Гуковский, проживающий по адресу улица Широкая, 23 (ныне Ленина, 33), назван владельцем кирпичного завода на Правом берегу Невы (Уткина заводь, 202). В аналогичной книге на 1917 г. он представлен как директор Бакинско-Астраханского нефтепромышленного и транспортного акционерного общества. Его назначение после Февраля казначеем ЦК и ПК РСДРП(б) означало, что большевикам понадобились и его деньги, и его связи.

В апреле Гуковский в числе немногих авторитетных большевиков был приглашён Лениным на совещание по стратегическим вопросам движения, но, как и другие участники, не поддержал курс на социалистическую революцию в форме вооружённого восстания. В ноябре Ленин не допустил его в руководство НКФ. Он был направлен в Главное Морское хозяйственное управление в качестве чрезвычайного комиссара по пересмотру смет всех ведомств. 13 декабря ларинский секретариат хозяйственной политики ВСНХ назначил его председателем совещания по финансированию предприятий. Находящееся после переворота в ведении Наркомвоенмора дореволюционное «Совещание по обороне», финансирующее военную промышленность, было переведено Лариным в подчинение ВСНХ с более широкими полномочиями. А в январе 1918 г. Ленин привлёк пока что не экспроприированного (?) бывшего капиталиста-нефтяника к подготовке национализации нефтяной промышленности, обсуждая с ним предложенные отделом топлива ВСНХ способы социализации отрасли. Результаты этих бесед вышли далеко за пределы нефтяной сферы. Очевидно, Гуковский проявил впечатлившую Ленина широту мышления, обратив его внимание на финансовые и международные аспекты планируемой национализации. Исследователь истории нефтяного дела в России В.Н. Косторниченко отнюдь не случайно назвал 
Гуковского «опытным специалистом по финансам» [16, с. 88]. Кроме того, он по роду своей деятельности имел контакты с многими иностранными представителями нефтяного бизнеса в России и хорошо понимал, к каким последствиям приведёт национализация их собственности. Сохранение таких контактов могло бы способствовать взаимовыгодному сотрудничеству и в бизнесе и в политике в условиях ненадёжного мира с Германией. Скрытые для сторонних наблюдателей мотивы принятия ленинских решений привели к довольно неожиданным следствиям.

2 марта ВСНХ в лице ближайшего в то время «экономического советника» Ленина Ю. Ларина, называемого А.С. Изгоевым «руководителем большевистской экономической политики» [13, с. 164], подчёркивая необходимость должной организации нефтяного дела, решил создать чрезвычайный Нефтяной комиссариат и принял постановление об учреждении должности Главного комиссара над нефтяной промышленностью с предоставлением ему широких полномочий, включая контроль над всем делом финансирования отрасли, взимания сборов с нефтепромышленных фирм, концентрируемых на его текущем счету. Это событие в деталях не отражено в отечественной литературе из-за особенностей его оформления. Документ был подписан, как это не раз бывало в специфических обстоятельствах: «За Президиум Высшего Совета Народного Хозяйства Ю. Ларин» [26]. Были случаи, когда Ларин подписывался и за председателя СНК, не уведомляя его об этом. По данным Р.М. Савицкой, тогда же, 2 марта на вновь учреждённую должность был назначен Гуковский [36, с. 98]. В этот же день было сделано и первое вложение в разрабатываемую нефтяную политику: Совнарком выделил ВСНХ аванс в 2 млн. рублей [9, с. 596].

По данным В.В. Журавлёва, Гуковский был назначен Главным комиссаром по нефти 8 марта [11, с. 211]. Очевидно, это мнение компетентного историка объясняется тем, что на следующий день, 9 марта, перед отъездом правительства в Москву, на заседании СНК Гуковскому поручили подобрать хорошо знающих, опытных людей в комиссары по нефтяному делу. Закрепляя 
особый статус Гуковского, Ленин на этом заседании провёл постановление и о его назначении заместителем наркома финансов. Тем самым он сохранял практически неизвестного историкам бывшего нефтепромышленника и большевистского «финансового магната» под своим контролем.

Не только «левые коммунисты» не поняли и не одобрили прагматизма вождя. Большевики Петрограда считали Гуковского крупным «буржуем», деньгами проложившим себе дорогу в высшие сферы «пролетарской» власти. Своеобразной была и его репутация в «массах» Москвы. Известный российский историк Ю.В. Готье, бывший с дореволюционных времён профессором Московского университета и ряда других вузов, прошедший Ухтино-Печорский лагерь и ссылку, впоследствии - академик АН СССР упоминал его в апрельской дневниковой записи 1918 г.: «...тов. Гуковский, нечто вроде министра финансов (говорят, что он не большевик, а спекулянт)» [7, с. 132]. Однако Ленин полностью доверял специфическому, имеющему особые заслуги большевику. Об этом свидетельствует написанная им 1 апреля 1918 г. записка управляющему Московской конторой Государственного банка Т.И. Попову, которой он закрепил фактически монопольное (за исключением самого председателя СНК) право Гуковского распоряжаться имеющимся золотым запасом [23, с. 73$]$.

Возвышение Гуковского в марте 1918 г. стало составным элементом меняющейся в условиях «мирной передышки» политики Ленина. Март и апрель воспринимались современниками и многими историками как крутой поворот от жёсткого и бескомпромиссного классового подхода к сотрудничеству с национальной и мировой буржуазией. Особенно наглядно это проявилось в изменении его отношения к нефтяной промышленности. До начала марта он настойчиво и последовательно добивался реализации подчёркнутой ещё в сентябре 1917 г. в «Грозящей катастрофе» обязательности национализации отрасли [21, т. 34, с. 169]. 1 марта даже было принято постановление о порядке и способах осуществления национализации нефтяной отрасли. Однако вплоть до 20 июня 1918 г. Совнарком к вопросу о национализации нефтяной 
промышленности больше не возвращался; хотя попытки его включения в повестки дня заседаний предпринимались, он не обсуждался. Ленин вслед за Гуковским неоднократно повторял, что эта мера не только не восстановит, но и еще более разрушит нефтяную промышленность. Ставился вопрос о привлечении к развитию отрасли иностранного капитала посредством предоставления концессий.

При этом в экономике в целом продолжалась реализация экономической программы, основные положения которой были сформулированы в «Декабрьском плане» Ларина [18], ленинском «Проекте декрета о социализации народного хозяйства» [21, т. 35, с. 174-175], в черновом наброске новой партийной программы [21, т. 36, с. 74-75]. Её ориентирами были: полное устранение буржуазии от влияния на экономическую жизнь; продолжение и завершение национализации промышленности; универсализация учёта и контроля «сначала рабочими организациями, затем поголовно всем населением»; введение всеобщей трудовой повинности, прежде всего, богатых и в то же время большинства рабочих и крестьян; замена торговли «планомерно организованным распределением»; принудительное объединение всего населения в потребительско-производительные коммуны и организация натурального продуктообмена города с деревенскими потребительными обществами мелких крестьян. В продиктованных между 23 и 28 марта стенографу Я.В. Хлебникову «Тезисах о задачах Советской власти в настоящий момент», названных издателями так называемого полного собрания сочинений «Первоначальным вариантом статьи “Очередные задачи Советской власти”» [21, т. 36, с. 127-164], Ленин развил сформулированные им ещё в сентябре 1917 г. условия удержания большевиками власти. «Нам надо заставить работать в новых организационно-государственных рамках, - писал он тогда. Недостаточно “убрать вон” капиталистов, надо (убрав вон негодных, безнадёжных “сопротивленцев”) поставить их на новую государственную службу. Это относится и к капиталистам и к известному верхнему слою буржуазной интеллигенции, служащих и т. д.» [21, т. 34, с. 311]. «Пролетариат 
сделает так, когда победит: он посадит экономистов, инженеров, агрономов и пр. под контролем рабочих организаций за выработку “плана”, за проверку его, за отыскивание средств сэкономить труд централизацией, за изыскание мер и способов самого простого, дешёвого, удобного и универсального контроля. Мы заплатим за это экономистам, статистикам, техникам хорошие деньги, но... но мы не дадим им кушать, если они не будут выполнять этой работы добросовестно и полно в интересах трудящихся» [21, т. 34, с. 320]. Для реализации этих предначертаний необходимо было сосредоточить в руках государства не только весь денежный фонд, но и все продовольственные ресурсы страны. Начать преобразования в этом направлении Ленин хотел с «нейтрализации» денег. Их «хранение и прятание» он назвал в тезисах формами сопротивления богатых советской власти, а сами деньги (денежные знаки) - «свидетельствами на взимание дани с трудящихся» [21, т. 36, с. 134135]. Поэтому, заключает он, «учёт и контроль за производством и распределением продуктов Советская власть вынуждена начать с организованной борьбы против богатых и имущих классов, утаивающих от всякого государственного контроля громадные суммы денежных знаков... Советская власть должна будет соединить введение трудовой повинности с регистрацией прежде всего (выделено мной - В.О.) представителей буржуазии и имущих классов, должна будет потребовать соответствующего истине заявления (декларации) о количестве имеющихся денежных знаков, должна будет принять ряд мер к тому, чтобы это требование не оставалось на бумаге, должна будет обдумать переходные мероприятия к сосредоточению всех запасов денежных знаков в Государственном банке или в его отделениях. Без такого рода мероприятий учёт и контроль за производством и распределением продуктов не может быть доведён до конца» [21, т. 36, с. 135-136]. При осуществлении денежной реформы Ленин предполагал менять все виды старых денег на новые, советские, в количестве не более 10 тыс. рублей. Подразумевалось обязательное, под страхом самых суровых кар, их держание в банках при количественных ограничениях, нормированных государством выдач 
со счетов в условиях безудержной инфляции, что и должно было привести к уничтожению денежных накоплений и превращению всех держателей денег в служащих (слуг) советской власти.

Гуковский был против подобной реформы, вполне справедливо полагая, что она не только вызовет мощное сопротивление, но и не будет способствовать стабилизации экономики и, в конечном счёте, укреплению власти. Ленин, казалось, прислушался к его мнению, тем более что в осуществимости требования обязательного держания денег в банках сомневался и пользующийся особым доверием вождя Я.С. Ганецкий. В окончательном варианте статьи «Очередные задачи Советской власти», написанном во второй половине апреля, о деньгах - лишь одно упоминание: «Веди аккуратно и добросовестно счёт денег...» [21, т. 36, с. 174]. Однако, как показали последующие события, это не означало, что Ленин изменил свои взгляды и убеждения, а было лишь тактическим манёвром, проявлением своеобразной социальной мимикрии. К этому времени вождь уже пришёл к выводу о необходимости строительства «коммунистической России» «некоммунистическими руками», используя при этом испорченный «буржуазной идеологией» «человеческий материал» [см.: 21, т. 37, с. 407-411], «перевоспитывая» его, насколько это возможно. Именно в таком контексте следует воспринимать его призывы «учиться социализму... у руководителей трестов», ...«привлечь к содействию Советской власти большое число представителей буржуазной интеллигенции...» [21, т. 36, с. 137, 138].

Гуковский на первых порах не поддавался «воспитанию», за что и поплатился. После упомянутого выше его доклада на заседании ВЦИК 15 апреля он подвергся резкой критике «левыми коммунистами» за предложения стабилизации денег и кредита, причём оппозиция против него была настолько велика, что ставился вопрос о его немедленном смещении с поста наркома. Ленин не стал брать его под свою защиту. Гуковский на протяжении всей дальнейшей финансовой деятельности наталкивался на глухое противодействие «левых». 
17 мая декретом СНК был учреждён Главный нефтяной комитет, должность Главного комиссара по нефтяным делам была упразднена. 28 мая - 2 июня была разыграна комбинация национализации нефтяного дела в Азербайджане. После получения телеграммы Сталина о национализации нефтяной промышленности центральным правительством соответствующий местный декрет был принят 1 июня Бакинским Совнаркомом и опубликован 2 июня. Национализировали 468 предприятий. В изданной в 1999 г. книге доктор исторических наук А.А. Иголкин высказывал предположение о том, что Сталин действовал по тайному указанию Ленина, все заявления которого о невозможности такой национализации были лишь хорошо отработанной акцией прикрытия $[12$, с. 85,89$]$. Считается, что в Москве узнали о «бакинской инициативе» 11 июня. После неоднократных сношений с Баку, неоднократно описанных в литературе, уступив его нажиму, СНК РСФСР принял декрет о национализации нефтяной промышленности в масштабах страны. В.Н. Косторниченко не согласился с «конспиративной теорией» Иголкина, направленной «неизвестно против кого» [16, с. 96]. На основании предыдущего изложения можно утверждать, что, если не заговор, то многоходовая интрига была направлена против «воспитуемого» Гуковского. Наконец, 28 июня спешным принятием широко известного декрета СНК была завершена другая задуманная в Москве и мастерски проведенная в Берлине Лариным при содействии Красина и Сокольникова интрига по национализации крупной и средней промышленности. Там наряду с другими вопросами оговаривались условия национализации в России акционерных обществ с участием германского капитала, но в Москве воспользовались случаем чтобы «заодно» национализировать все более или менее значительные предприятия и железные дороги. Неизвестно, нанесли ли эти национализации ущерб личным интересам Гуковского, но он вплоть до своей отставки сопротивлялся их фактической реализации [см.: 30, с. 42-43].

Добросовестный Соломон, характеризуя Гуковского до его приезда в Ревель, констатировал: «Всеобщий отзыв о нём был, как о человеке весьма 
честном» [40, с. 304]. О высоком доверии к нему руководства страны свидетельствует сам факт предоставления в его распоряжение огромных ценностей. Но, очевидно, осуществляя фактически контрабандные сделки за счёт «награбленных» «пролетарским государством» богатств Гуковский поновому осмыслил или, скорее, интуитивно-подсознательно прочувствовал всё произошедшее с ним, ему подобными, всей Россией, претерпел катастрофический психологический сдвиг. Неизвестно, на какую сумму олицетворяющий большевизм Ленин, выражаясь в терминах определённого сектора финансовых отношений, «кинул» его лично. Но выпивая, закусывая и излишествуя, подкармливая многих большевистских руководителей, оказавшихся под водительством вождя в катастрофических условиях жизни, распоряжаясь деньгами по своему усмотрению, он как бы реализовывал своё право на моральную сатисфакцию.

Гуковский ушёл из жизни в ноябре 1921 г. политическим и нравственным изгоем. Обстоятельства его ухода из жизни трактуются по-разному. Не всегда точный и добросовестный Ларсонс писал: «В конце концов, Гуковский был отозван в Москву и там покончил жизнь самоубийством. На его похоронах не присутствовал никто из видных представителей советской власти» [20, с. 47]. Соломон передаёт то, что он слышал от других: «...Гуковский был предан суду. Но он захворал какой-то таинственной болезнью, по официальным сведениям, это было воспаление лёгких. Он скончался в страшных мучениях... В советских кругах говорят, передавая эту версию как страшную тайну, что Гуковский был отравлен, чтобы без суда и следствия покрыть могильной плитой вместе с его бренным телом и его (его ли только?) преступления, в которых были замешаны многие» [40, с. 500]. Живущий в Латвии российский журналист А.Г. Мосякин, пишущий о расхищении государственного достояния, утверждает: «Осенью 1921 года Гуковский был арестован и при загадочных обстоятельствах умер на Лубянке в тюрьме ВЧК» [24]. Ещё один штрих к информации об уходе Гуковского добавляет мемориальное издание середины 20-х гг.: «Вследствие постигшего его несчастья (его переехал автомобиль) здоровье и 
работоспособность его в последний период его жизни были надломлены. Осенью 1921 г., во время приезда в Москву, он умер от воспаления лёгких» [34, с. 171]. Заметим попутно, что в так называемой свободной энциклопедии Википедия уже много лет повторяют, что Гуковский умер в Таллине (Ревеле).

В заключение стоит вспомнить, что Гуковский в пылу дискуссии с Соломоном и его юристами вдохновенно заявил: «Правда выше всяких интересов, и даже государственных!! И я твердо верю в неё! Я знаю, что в качестве государственного деятеля этой эпохи, когда мне выпало на долю творить историю, я являюсь историческим лицом... И вот беспристрастная история поддержит меня, она скажет своё беспристрастное слово....» [40, с. 395 396]. Как видно, Гуковский не страдал излишней скромностью. Но о его словах стоит задуматься. В них есть определённая философия, свидетельствующая о том, что Гуковский не был никчемным человеком.

\section{Список литературы}

1. Боголепов Д. Финансовое строительство в первые годы Октябрьской революции // Пролетарская революция. 1925. № 4. С. 149-178.

2. Большая Советская Энциклопедия. 1-е изд. Т. 19. / Под общ. ред. В.В. Куйбышева, М.Н. Покровского, Н.И. Бухарина и др.; гл. ред. О.Ю. Шмидт. М.: Сов. энцикл., 1930. 844 стлб.

3. Бухарин Н.И., Преображенский Е.А. Азбука коммунизма: Популярное объяснение программы Российской Коммунистической партии (большевиков). М.: Госиздат, 1920. 342 с.

4. Бухарин Н.И. Экономика переходного периода. Ч. 1. Общая теория трансформационного процесса. М.: Гос. изд-во, 1920. 157 с.

5. Генкина Э.Б. Протоколы Совнаркома РСФСР как исторический источник для изучения государственной деятельности В.И. Ленина / АН СССР. Ин-тут истории СССР. М.: Наука, 1982. 193 с.

6. Гимпельсон Е.Г. Великий Октябрь и становление советской системы управления народным хозяйством (ноябрь 1917 - 1920 гг.). М.: Наука, 1977. $310 \mathrm{c}$. 
7. Готье Ю.В. Мои заметки. М.: ТЕРРА, 1997. 592 с.

8. Гуманитарные проблемы современности: человек и общество: моногр. Кн. 28 / Д.Е. Барашева, Л.С. Бороненкова, И.Г. Долинина и др. Новосибирск: Изд-во Центра развития научного сотрудничества, 2016. С. 107-155.

9. Декреты Советской власти. Т. 1. 25 окт. 1917 г. - 16 марта 1918 г. М.: Госполитиздат, 1957. XI, $626 \mathrm{c.}$

10. Деятели СССР и революционного движения России. Энцикл. словарь Гранат. Репринтное изд. М.: Сов. энцикл., 1989. 832 с.

11. Журавлев В.В. Декреты Советской власти 1917-1920 гг. как исторический источник. М.: Наука, 1979. 399 с.

12. Иголкин А.А. Отечественная нефтяная промышленность в 1917-1920 гг. М.: РГГУ, 1999. 187 с.

13. Изгоев А.С. Социализм, культура, большевизм // Из глубины. Сб. статей о русской революции. М.: Изд-во Моск. ун-та, 1990. С. 151-173.

14. Ирошников М.П. Председатель Совета народных комиссаров. В. Ульянов (Ленин). Очерки государственной деятельности в 1917-1918 гг. Л.: Наука. Ленингр. отд., 1974. 448 с.

15. История российского Министерства финансов в лицах его руководителей / сост. В.Н. Шитов. Ульяновск: УлГТУ, 2011. 99 с.

16. Косторниченко В.Н. К вопросу о национализации отечественной нефтяной промышленности в 1918 г. // Экономическая история. Обозрение / Под ред. Л.И. Бородкина. Вып. 10. М.: Изд-во МГУ, 2005. С. 80-100.

17. Ларин Ю. Итоги, пути, выводы новой экономической политики М.: Моск. рабочий, 1923. 287 с.

18. Ларин Ю. Проект декрета СНК о плане национализации // Российский государственный архив экономики. Ф. 9690. Оп. 3. Д. 4. Л. 1-1об.

19. Ларин Ю. (Лурье М.) Трудовая повинность и рабочий контроль. Пг.: Книга, 1918. 102 с.

20. Ларсонс М.Я. В советском лабиринте. Эпизоды и силуэты. Париж: Изд-во «Стрела», 1932. 184 с. 
21. Ленин В.И. Полное собрание сочинений. Т. 33-45. М.: Политиздат, 1969-1981.

22. Ленинский сборник XXI. М.: Партиздат, 1933. 323 с.

23. Ленинский сборник XXXVII. М.: Политиздат, 1970. 398 с.

24. Мосякин А. Балтийский оффшор // Isrorija. 2001. № 13. URL: http://www.baltkurs.com/russian/arhiv/13/istor.htm (дата обращения: 30.11.2018).

25. Народный комиссариат финансов РСФСР. Материал из Википедии свободной энциклопедии. URL: https://ru.wikipedia.org/wiki/Народный_ комиссариат_финансов_РСФСР (дата обращения: 15.01.2019).

26. О Главном Комиссаре над нефтяной промышленностью. Постановление Высшего Совета Народного Хозяйства. 2 марта 1918 г. URL: http://istmat.info/node/28971 (дата обращения: 11.01.2019).

27. Ольшевский В.Г. Идея социализма и деньги: столетие несостоявшегося эксперимента // Евразийский союз учёных. 2017. № 9 (42). С. $18-22$.

28. Ольшевский В.Г. Идеология и психология российского большевизма: становление, основные черты и особенности // История российской психологии в лицах: Дайджест. 2018. № 4. С. 78-104. URL: http://journals.hist-psy.ru/ index.php/HPRPD/article/view/461 (дата обращения: 25.01.2019).

29. Ольшевский В.Г. И.Э. Гуковский как субъект и объект психологической истории // Историко-психологические аспекты 1917 г.: Материалы XLII Междун. науч. конф. Санкт-Петербург, 4 дек. 2017 г. / Под ред. д-ра ист. наук, проф. С.Н. Полторака. СПб.: Полторак, 2017. С. 87-94.

30. Ольшевский В.Г. Финансово-экономическая политика советской власти в 1917-1918 гг.: тенденции и противоречия // Вопр. истории. 1999. № 3. C. 28-45.

31. Ольшевский В.Г. Человек в истории и история в жизни человека: депутат государственной думы, уфимский городской голова, нарком РСФСР А.И. Бриллиантов // Историческая психология и геополитика: Матер XLI 
Междун. науч. конф. Санкт-Петербург, 18 мая 2017 г. / Под ред. д-ра ист. наук, проф. С.Н. Полторака. СПб.: Полторак, 2017. С. 31-37.

32. Осинский Н. Строительство социализма. Общие задачи. Организация производства. М.: Изд-во «Коммунист», 1918. 159 с.

33. Островский А.В. Кто стоял за спиной Сталина? СПб.: ИД «Нева», М.: Олма-Пресс, 2004. 642 с.

34. Памятник борцам пролетарской революции, погибшим в 1917-1921 гг. / Сост. Л. Лежава и Г. Русаков. 3 изд., испр. и доп. М.: Госиздат, 1925. 780 с.

35. Первое советское правительство. Октябрь 1917 - июль 1918 / Науч. ред. А.П. Ненароков. М.: Политиздат, 1991. 461 с.

36. Савицкая Р.М. Очерк государственной деятельности В.И. Ленина. Март - июнь 1918 г. М.: Мысль, 1969. 436 с.

37. Советский энциклопедический словарь. / Гл. ред. А.М. Прохоров. Изд. 2-е. М.: Сов. энцикл., 1983.1600 с.

38. Соколов Е.Н. Финансовая политика советской власти (октябрь 1917 август 1918 гг.). Монография. Ряз. гос. ун-т им. С.А. Есенина. Рязань, 2008. $148 \mathrm{c}$.

39. Соколов Е.Н. Финансовая политика советского правительства (март август 1918 г.) // Преподаватель. XXI век. 2010. № 1. С. 237-244.

40. Соломон Г.А. Среди красных вождей. Лично пережитое и виденное на советской службе. В 2 т. Париж: Изд-во «Мишень», 1930. Т. 1. С. 1-334; Т. 2. С. 335-604.

41. Суханов Н.Н. Записки о революции: В 3 т. Т. 2. М.: Политиздат, 1991. 399 c.

(c) Ольшевский В.Г., 2019 